\title{
Pengaruh Pengaturan Suhu Penggorengan Vacum Terhadap Sifat-Sifat Kimia Keripik Salak
} (Salaca edulis Reinw)

\section{Effects of Vacuum Frying Temperature on The Chemical Characteristics of Snake Fruit (Salaca edulis Reinw) Chips}

\author{
Rachel Breemer*, Syane Palijama, Febry R. Palijama \\ Jurusan Teknologi Hasil Pertanian Fakultas Pertanian Universitas Pattimura \\ Jl. Ir. M. Putuhena Kampus Poka Ambon 97233 \\ *Penulis Korespondensi: E-mail: rachelbreemer@yahoo.com
}

\begin{abstract}
Snake fruit (Salaca edulis Reinw) has a taste of sweet and sour, with a strong astringent edge. Snake fruit can be processed into chips in order to prolong its shelf life. Fruit chips processed with vacuum frying technology does not compromise the form, taste, colour, and aroma of the native fruits. However, in an effort to obtain crisp and tasteful snake fruit chips, the temperature of the vacuum frying process should be adjusted accordingly. Results showed the frying temperature of $70^{\circ} \mathrm{C}$ resulted in the chips which had Vitamin $\mathrm{C}$, total acidity, and moisture contents of $0.11 \mathrm{mg}, 16.05 \%$, and $12.74 \%$, respectively. When chips were fried with $80^{\circ} \mathrm{C}$, the resulting product had a Vitamin C of $0.12 \mathrm{mg}$, total acidity of $16.14 \%$, and moisture of $14.02 \%$. Whereas chips with lower Vitamin $\mathrm{C}$, total acidity, and moisture contents of $0.09 \mathrm{mg}, 8,54 \%$, and $6.01 \%$, subsequently resulted from frying with $90^{\circ} \mathrm{C}$.
\end{abstract}

Keywords: chips, snake fruits, vacuum frying

\begin{abstract}
ABSTRAK
Salak (Salaca edulis, Reinw) memiliki daging buah yang berasa sepat, asam manis, dan sepat manis. Salak dapat diolah menjadi keripik dengan tujuan untuk memperpanjang umur simpan. Keripik buah yang diolah dengan teknologi penggorengan sistem hampa (vacuum frying) menghasilkan kripik dengan bentuk, rasa, warna dan aroma asli dari buah segar yang diolah. Namun untuk mendapatkan kripik buah salak yang renyah dan gurih diperlukan pengaturan suhu yang tepat sehingga dapat menghasilkan produk yang baik. Hasil penelitian menunjukkan bahwa pada suhu penggorengan $70^{\circ} \mathrm{C}$ menghasilkan vitamin sebesar $0,11 \mathrm{mg}$, total asam sebesar $16,05 \%$ dan kadar air sebesar $12,74 \%$. Untuk perlakuan suhu $80^{\circ} \mathrm{C}$ menhasilkan vitamin $\mathrm{C}$ sebesar 0,12 mg, total asam sebesar 16,14\%, dan kadar air sebesar 14,02\%. Sedangkan perlakuan suhu penggorengan $90^{\circ} \mathrm{C}$ menghasilkan vitamin $\mathrm{C}$ sebesar $0,09 \mathrm{mg}$, total asam sebesar $8,54 \%$ dan menhasilkan kadar air yang lebih rendah yaitu sebesar $6,01 \%$.
\end{abstract}

Kata kunci: keripik, penggorengan hampa, salak

\section{PENDAHULUAN}

Salak (Salaca edulis Reinw) merupakan buah tropis yang sangat populer di Indonesia dan mempunyai prospek yang baik untuk pemasaran dalam negeri maupun luar negeri. Salak memiliki rasa yang sepat, asam manis dan sepat asam manis. Kualitas buah salak yang dikehendaki konsumen umumnya mempunyai daging buah yang tebal, biji kecil, kadar taninnya rendah, manis, dan tidak berair, serta warna kulit buah kecoklatan (Santoso, 1990).

Umumnya salak dikonsumsi dalam bentuk buah segar, namun jika buah salak dibiarkan terlalu masak terlihat bagian kulit yang pecah-pecah sehingga kurang diminati, selain itu buah salak 
setelah dipanen memiliki sifat tidak tahan untuk penyimpanan jangka panjang dan membutuhkan ruangan yang cukup besar karena ukurannya dan jumlahnya yang banyak (Nugraha et al., 2012). Oleh karena itu perlu dilakukan pengolahan salah satunya dengan diolah menjadi keripik agar dapat memperpanjang umur simpan salak sehingga bisa dikonsumsi dalam jangka waktu yang lama.

Keripik buah merupakan hasil olahan produk buah segar dalam bentuk makanan ringan (chip) yang diolah dengan teknologi penggorengan sistem hampa (vacuum frying). Keripik buah hasil penggorengan sistem hampa memiliki rasa, aroma, seperti buah aslinya, tekstur renyah serta nilai gizinya yang relatif dapat dipertahankan (Tumbel dan Manurung, 2017).

Beberapa penelitian terkait pengolahan keripik dengan menggunakan teknologi penggorengan sistem hampa (vacuum frying) telah dilakukan antara lain Iswari (2013) pada keripik ubi jalar, Wijayanti et al. (2011) pada keripik pisang dan Tumbel dan Manurung (2017) pada keripik nanas. Hasil penelitian menunjukkan bahwa umumnya pengolahan dengan peng-gorengan hampa memperbaiki sifat fisikokimia dan organoleptik keripik yang dihasilkan.

\section{Bahan}

\section{METODE PENELITIAN}

Bahan yang digunakan dalam penelitian ini adalah daging buah salak manado, air bersih, minyak goreng (Bimoli), garam (Dolpin). Bahan untuk analisis antara lain larutan iodium, akuades, dan $\mathrm{NaOH}$.

\section{Pelaksanaan Penelitian}

\section{Pembuatan Keripik Buah Salak}

Buah yang digunakan untuk keripik salak dipilih yang matang, segar dan tidak memar. Buah salak dikupas kulitnya, dibelah daging buahnya dan dibuang bijinya, kemudian diiris dan dicuci bersih. Daging buah di blansir dengan uap pada suhu $100^{\circ} \mathrm{C}$ selama 10 menit. Selanjutnya direndam dalam larutan air garam 0,5 persen selama 5 menit, kemudian ditiriskan sebentar dan dicuci kembali. Setelah itu irisan salak digoreng selama 1 jam menggunakan vacuum frying sesuai perlakuan yaitu pada suhu $70^{\circ} \mathrm{C}, 76 \mathrm{~cm} \mathrm{Hg}, 80^{\circ} \mathrm{C}, 76 \mathrm{~cm} \mathrm{Hg}, 90^{\circ} \mathrm{C}$, $76 \mathrm{~cm} \mathrm{Hg}$. Setelah matang, keripik salak diangkat lalu ditiriskan dan kemudian siap dikemas.

\section{Uji Kimia}

Analisis kimia yang dilakukan terhadap keripik salak meliputi kadar vitamin C (Sudarmadji et al., 1996), total asam dan kadar air dengan metode oven (AOAC, 2000).

\section{Analisa Data}

Data yang telah terkumpul selanjutnya dianalisis dengan menggunakan analisis sidik ragam yang disesuaikan dengan rancangan yang digunakan. Apabila terdapat pengaruh nyata dan sangat nyata antara perlakuan yang dicobakan, maka dilanjutkan dengan uji Beda Nyata Jujur.

\section{PEMBAHASAN}

\section{Vitamin C}

Vitamin C (asam askorbat) merupakan antioksidan alami yang mudah dan murah bila dikonsumsi dari alam. Vitamin $\mathrm{C}$ sebagai antioksidan berfungsi untuk mengikat oksigen sehingga tidak mendukung reaksi oksidasi namun vitamin $\mathrm{C}$ bersifat tidak stabil, bila terkena cahaya dan pada suhu tinggi mudah mengalami kerusakan. Vitamin C merupakan salah satu vitamin yang memiliki sifat tidak tahan panas dan dan mudah menguap sehingga mulai hilang sejak awal persiapan bahan ketika bahan kontak dengan udara dan kerusakan utama selama berlangsungnya proses pemanasaan (Winarno, 2002).

Tabel 1 menunjukkan bahwa kandungan vitamin $\mathrm{C}$ tertinggi terdapat pada perlakuan suhu $80^{\circ} \mathrm{C}$ yaitu sebesar $0,12 \mathrm{mg}$, sedangkan kandungan vitamin $\mathrm{C}$ terendah terdapat pada perlakuan suhu $90^{\circ} \mathrm{C}$ yaitu sebesar $0,09 \mathrm{mg}$. Hasil uji beda nyata jujur menunjukkan perlakuan suhu $80^{\circ} \mathrm{C}$ tidak berbeda nyata dengan perlakuan suhu $70^{\circ} \mathrm{C}$ tetapi berbeda nyata dengan perlakuan suhu $90^{\circ} \mathrm{C}$. Hal ini menunjukkan bahwa semakin tinggi suhu penggorengan akan menurunkan nilai kadar vitamin $\mathrm{C}$ keripik salak. Hasil yang sama juga ditunjukkan oleh Widaningrum et al. (2008), dimana kadar vitamin $\mathrm{C}$ pada keripik buncis muda yang digoreng vakum mengalami penurunan ketika semakin tinggi suhu penggorengan yang digunakan. Kandungan vitamin C pada keripik salak berkurang karena pada saat penggorengan menggunakan vacuum frying dengan suhu tinggi dapat merusak vitamin $\mathrm{C}$ seperti 
yang dikemukakan oleh Apandi (1984) bahwa vitamin $\mathrm{C}$ dapat hilang karena panas.

Hasil penelitian menunjukkan bahwa total asam tertinggi terdapat pada perlakuan dengan suhu penggorengan $80^{\circ} \mathrm{C}$ yaitu sebesar $16,14 \%$, sedangkan total asam terendah terdapat pada perlakuan suhu $90^{\circ} \mathrm{C}$ yaitu sebesar $8,54 \%$. Uji beda nyata jujur menunjukkan bahwa perlakuan suhu $80^{\circ} \mathrm{C}$ tidak berbeda nyata dengan perlakuan suhu $70^{\circ} \mathrm{C}$ tetapi berbeda nyata dengan pelakuan suhu $90^{\circ} \mathrm{C}$ (Tabel 1). Semakin tinggi suhu penggorengan vakum, semakin rendah kadar total asam yang dihasilkan. Hal ini menunjukkan bahwa perlakuan penggorengan dengan suhu tinggi menyebabkan kandungan asam pada keripik salak menjadi terurai sehingga berpengaruh terhadap rendahnya kadar total asam.

Penurunan total asam disebabkan oleh semakin lama pemanasan maka asam-asam organik seperti asam sitrat, asam askorbat mengalami kerusakan sehingga berdampak pada penurunan total asam keripik salak (Winarno, 2002). Faktor lain yang melatar belakangi terjadinya peningkatan dan penurunan total asam yaitu disebabkan oleh peningkatan senyawa ion $\mathrm{H}^{+}$sehingga mengakibatkan $\mathrm{pH}$ mengalami kenaikan yang berdampak pada total asam yang dihasilkan. Perlakuan perendaman buah salak dalam larutan garam pada pembuatan keripik dapat meningkatkan senywa ion $\mathrm{H}^{+}$sehingga berpengaruh terhadap total asam keripik salak yang dihasilkan.

\section{Kadar Air}

Hasil penelitian menunjukkan bahwa kadar air tertinggi terdapat pada perlakuan suhu $80^{\circ} \mathrm{C}$ yaitu sebesar $14,02 \%$ sedangkan kadar air terendah terdapat pada perlakuan suhu $90^{\circ} \mathrm{C}$ yaitu sebesar $6,01 \%$. Hasil uji beda nyata jujur menunjukkan bahwa perlakuan suhu $80^{\circ} \mathrm{C}$ tidak berbeda nyata dengan perlakuan suhu $70^{\circ} \mathrm{C}$ tetapi berbeda nyata dengan perlakuan suhu $90^{\circ} \mathrm{C}$ (Tabel 1). Semakin tinggi suhu penggorengan, maka semakin rendah kadar air keripik salak yang dihasilkan. Hasil yang sama juga ditunjukkan oleh Tumbel dan Manurung (2017) dimana semakin tinggi suhu penggorengan maka semakin besar air yang menguap sehingga air yang terkandung pada keripik nanas semakin berkurang.

Berdasarkan hasil pengamatan terlihat bahwa nilai kadar air keripik salak yang dihasilkan belum memenuhi syarat mutu keripik menurut Standar Nasional Indonesia yaitu maksimalnya 6\% (BSN, 1996), namun perlakuan suhu $90^{\circ} \mathrm{C}$ kadar airnya hampir sama dibandingkan perlakuan suhu $70^{\circ} \mathrm{C}$ dan suhu $80^{\circ} \mathrm{C}$ yaitu $6,01 \%$. Rendahnya kadar air pada keripik salak yang digoreng pada suhu $90^{\circ} \mathrm{C}$ menyebabkan keripik dapat disimpan dalam waktu yang cukup lama. Apabila kadar air dalam produk keripik tinggi maka keripik akan lembab, sehingga teskturnya menjadi tidak renyah. Hal ini akan mengurangi akseptabilitas konsumen.

\section{KESIMPULAN}

Dari hasil penelitian dapat disimpulkan bahwa, perlakuan suhu penggorengan vakum berpengaruh nyata terhadap perubahan kandungan vitamin $\mathrm{C}$, total asam dan kadar air keripik salak. Perlakuan suhu $70^{\circ} \mathrm{C}$ menghasilkan vitamin sebesar $0,11 \mathrm{mg}$, total asam sebesar $16,05 \%$, dan kadar air sebesar $12,74 \%$. Untuk perlakuan suhu $80^{\circ} \mathrm{C}$ menghasilkan vitamin $\mathrm{C}$ sebesar $0,12 \mathrm{mg}$, total asam sebesar 16,14\% dan kadar air sebesar 14,02\%. Sedangkan perlakuan suhu penggorengan suhu $90^{\circ} \mathrm{C}$ menghasilkan vitamin $\mathrm{C}$ sebesar $0,09 \mathrm{mg}$, total asam sebesar $8,54 \%$ dan menghasilkan kadar air yang lebih rendah yaitu $6,01 \%$.

Tabel 1. Pengaruh suhu penggorengan vakum $\left({ }^{\circ} \mathrm{C}\right)$ terhadap vitamin $\mathrm{C}$, total asam dan kadar air keripik salak

\begin{tabular}{cccc}
\hline $\begin{array}{c}\text { Suhu Penggorengan } \\
\text { Vakum }\left({ }^{\circ} \mathbf{C}\right)\end{array}$ & Vitamin C (mg) & Total Asam (\%) & Kadar Air (\%) \\
\hline $70^{\circ}$ & $0,11 \mathrm{bc}$ & $16,05 \mathrm{~b}$ & $17,74 \mathrm{a}$ \\
$80^{\circ}$ & $0,12 \mathrm{~b}$ & $16,14 \mathrm{~b}$ & $14,02 \mathrm{a}$ \\
$90^{\circ}$ & $0,09 \mathrm{c}$ & $8,54 \mathrm{c}$ & $6,01 \mathrm{~b}$ \\
\hline
\end{tabular}




\section{DAFTAR PUSTAKA}

AOAC. 2000. Official Methods of Analysis. Association of Official Analytical Chemist. Inc. Arlington Virginia.

Apandi, M. 1984. Teknologi Buah dan Sayur. Penerbit Alumi. Bandung.

[BSN] Badan Standarisasi Nasional. 1996. Keripik Buah. SNI 01-4304-1996. Badan Standarisasi Nasional. Jakarta.

Iswari, N.M.C. 2013. Optimasi suhu dan waktu penggorengan hampa (vacuum frying) dalam produksi keripik ubi jalar Mentawai. [Skripsi] Departemen Teknik Mesin dan Biosistem, Fakultas Teknologi Pertanian, Institut Pertanian Bogor. Bogor.

Nugraha, S., Sugiyanto, N.F. Sulvana, R. Tito, dan K. Titis. 2012. Elastisitas dan Permintaan Hasil Pertanian. Makalah Tataniaga Pertanian, Universitas Sebelas Maret. Surakata.
Santoso, H.B. Salak Pondoh. Kanisius. Yogyakarta. Sudarmadji, S., B. Haryono, dan Suhardi. 1989. Analisa Bahan Makanan dan Pertanian. Liberty. Yogyakarta.

Tumbel, N. dan S. Manurung. 2017. Pengaruh suhu dan waktu penggorengan terhadap mutu keripik nanas menggunakan penggoreng vakum. Jurnal Penelitian Teknologi Industri 9: 9-22.

Widaningrum, N. Setyawan, dan D.A. Setyabudi. 2008. Pengaruh cara pembumbuan dan suhu penggorengan vakum terhadap sifat kimia dan sensori keripik buncis (Phaseolus radiatus) Muda. Jurnal Pascapanen 5: 4554.

Wijayanti, R., I.W. Budiastra, dan R. Hasbullah. 2011. Kajian rekayasa proses penggorengan hampa dan kelayakan usaha produksi keripik pisang. Jurnal Keteknikan Pertanian 25: 133 140.

Winarno, F.G. 2002. Kimia Pangan dan Gizi. Gramedia Pustaka Utama. Jakarta. 